\title{
Rainwater harvesting system for a sustainable water supply for the poor on Merbau island
}

\author{
Joleha $^{1^{*}}$, Aras Mulyadi ${ }^{2}$, Wawan $^{3}$, and Imam Suprayogi ${ }^{1}$ \\ ${ }^{1}$ Department of Civil Engineering, Universitas Riau, Pekanbaru, Indonesia \\ ${ }^{2}$ Department of Marine Science, Universitas Riau, Pekanbaru, Indonesia \\ ${ }^{3}$ Master of Agricultural Science, Universitas Riau, Pekanbaru, Indonesia
}

\begin{abstract}
Difficulty in meeting one's basic daily needs such as clean water in order to fulfill a healthy, clean and productive life is a significant problem for people living on remote islands. Rainwater is the only source of clean water for the community on Merbau Island because of the low quality of the surface and groundwater resources. The majority of Merbau Island is covered by peat and lowlands; hence the rainwater that falls on the land surface is generally contaminated with peat water, which tends to be more acidic. Frequent rainfall at the location produces an abundant volume of water that is sufficient enough to meet the collective household daily demand for clean water. However, the community is not able to provide a large rainwater harvesting facility that can minimize the loss of rainwater into the rivers or seas. This study aimed to obtain data on the field conditions used as the basis for planning RWH systems for domestic needs so as to meet the need for sustainable clean water on Merbau Island. The results show that the highest rainfall recorded in 2013 was 3,164.3 $\mathrm{mm}$. Such an amount of rainwater can fulfill the daily clean water requirements for each household on Merbau Island. The population of poor people on the island is approximately $44 \%$, which results in around $73 \%$ of people not having an adequate rainwater harvesting system. The average roof area data, the number of family members and the type of roof, being $213 \mathrm{~m}^{2}, 6$ people and zinc (0.9) respectively, using the Rain Cycle v2 software, obtained the result that a $12 \mathrm{~m}^{2}$ tank is needed to meet the need for clean water throughout the year.
\end{abstract}

\section{Introduction}

Indonesia is an archipelagic country made up of approximately 17,508 islands [1]. The islands in Indonesia are dominated by those that are small in size, one of which is Merbau Island located in Kepulauan Meranti, Riau Province. Like other islands in developing countries, many islands in Indonesia encounter economic and environmental shortcomings which result in the people having poor access to clean water [2].

\footnotetext{
* Corresponding author: jolehas@yahoo.com
} 
Usually, rainwater is harvested to meet the needs prompted by domestic, industrial, agricultural and environmental use [3-6]. Rainwater harvesting is also used for toilet flushing, washing, maintaining landscapes and for replenishing groundwater [6-7]. Many studies have suggested rainwater as an alternative due to water shortages as an effect of the population rise, climate change, and pollution [8]. Other studies have correlated rainfall and population density to assert an optimal tank size suggestion [9].

According to Julius et al. [10], rainwater harvesting could be one of the best methods available to restore the natural hydrologic cycle and to allow for sustainable urban development. Another objective of rainwater harvesting as mentioned by Ojwang et al. [11] is to examine some of the appropriate and feasible solutions to rainwater harvesting (RWH) techniques both technically and economically. This is to ensure that it is affordable for future users based on their hydrological, technical, social and cultural conditions. Bhattacharya [12] also mentioned some of the advantages of rainwater harvesting such as it is simple, cheap, replicable, efficient, sustainable and adaptable, applicable on a small scale, easily operated, highly adaptive and cost-efficient.

Despite the qualities of rainwater harvesting, its benefits cannot be obtained by the Merbau islanders, who primarily live in poverty [13] and who are unable to afford a simple rainwater reservoir. This study aims to collect data on the field conditions used as a basis for planning RWH systems for the villager's domestic needs to meet the demand for sustainable clean water on Merbau Island.

\subsection{Background}

This research study was conducted in the Merbau Island sub-district, which is the expansion of the Merbau sub-district. The capital city is Semukut village. The total area of Merbau Island is $380.40 \mathrm{~km}^{2}$. Geographically, Merbau Island has located 01002'45.72" NL and 102031'56.44" EL, as can be seen in Fig. 1.

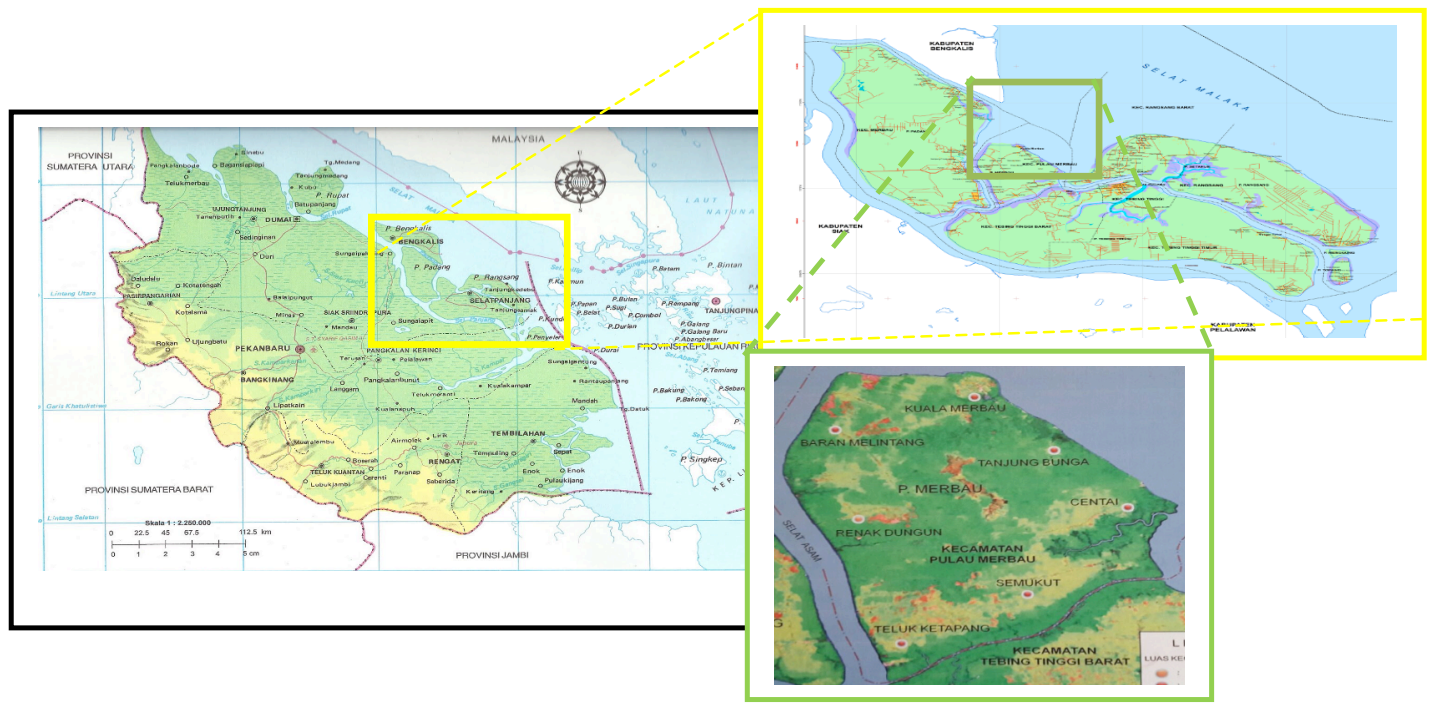

Fig. 1. Research site (modified from Google maps and the village profile [13]).

\subsubsection{Topography, weather and rainfalls}

Merbau Island has an area of $380.40 \mathrm{~km}^{2}$, which is surrounded by the Asam Strait, Air Hitam Strait and Malacca Strait [14]. The Meranti Islands District is affected by two 
seasons the southwest season that runs from May to October and the northeast season that runs from November to April.

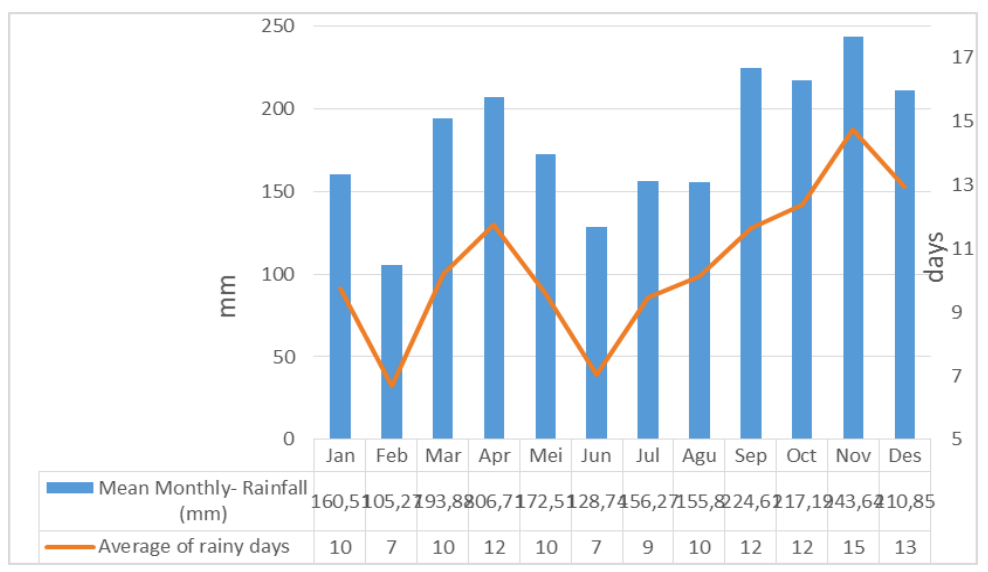

Fig. 2. Average monthly rainfall and the number of monthly rain days on Merbau Island 1997 to 2016.

The Sumatra wind from the mainland of North Sumatra takes the form of hurricanes carrying heavy rain, moving from the mainland of Sumatra to the East across the Melaka strait to the mainland of Malaysia. This generally occurs during the southwest season [15]. In general, the Indonesian territory around the equator is characterized by short dry seasons and long rainy seasons, and twice the maximum monthly rainfall in a year [16]. According to Worm and Hattum [17], rainfall is the key to knowing whether the use of rainwater harvesting systems can compete with the use of the water supply system of PDAMs (local water company). The average number of rainy days during 1997-2016 can be seen in Fig. 2.

\subsubsection{The demographic, social and economic situation of Meranti Island regency}

The data from the Bureau of Statistics of the Meranti Islands regency [18] shows the population of the Merbau Island sub-districts from 2012 to 2016 as can be seen in Table 1.

Table 1. Number and density of the Merbau population 2012-2016.

\begin{tabular}{|c|c|c|c|c|c|}
\hline \multirow{2}{*}{ Description } & \multicolumn{5}{|c|}{ Year } \\
\cline { 2 - 6 } & $\mathbf{2 0 1 2}$ & $\mathbf{2 0 1 3}$ & $\mathbf{2 0 1 4}$ & $\mathbf{2 0 1 5}$ & $\mathbf{2 0 1 6}$ \\
\hline Population & 15.031 & 15.091 & 14.791 & 14.889 & 14.975 \\
\hline Growth rate (\%) & - & $0.39 \%$ & - & $0.66 \%$ & $0.58 \%$ \\
\hline Density (person/Ha) & 0.40 & 0.40 & 0.39 & 0.39 & 0.39 \\
\hline
\end{tabular}

The Merbau Island people work as rubber farmers $(60 \%)$, coconut farmers $(5 \%)$, and sagu farmers $(15 \%)$, traders $(10 \%)$, government and private employees $(2 \%)$, fishers $(5 \%)$, and others $(3 \%)$ [13]. The distribution of the population and the number of poor people in each village in the Merbau Island sub-districts has been presented in Fig. 3. The average number of the poor in each village is up to $44.4 \%$ of the total population in each village. 


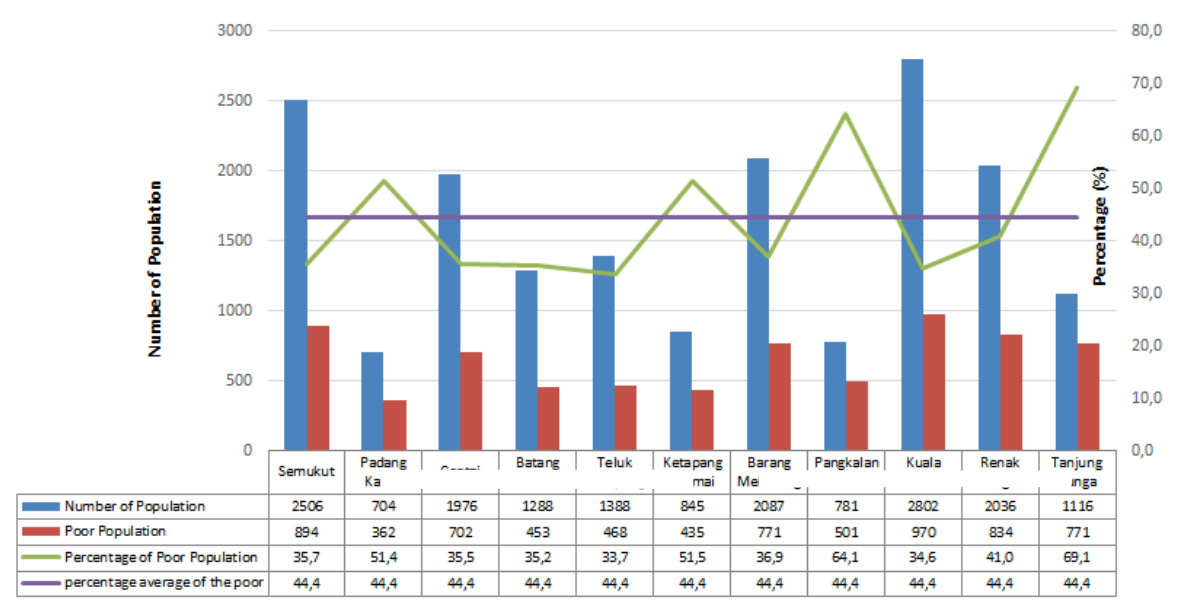

Fig. 3. The population in comparison to the poor percentage of the population in the Merbau Island sub-districts in 2015.

\subsubsection{Facilities and infrastructure for rainwater harvesting}

The facilities and infrastructure related to harvesting rainwater owned by the locals are quite traditional. The entire household-based infrastructure is not equipped with the proper components of a rainwater harvesting system, which should consist of the water collection area, the distribution system, and the storage tank. This condition inhibits the rainwater harvesting from functioning optimally as it cannot contain much water and the quality of the water is not hygienic enough (Fig. 4).
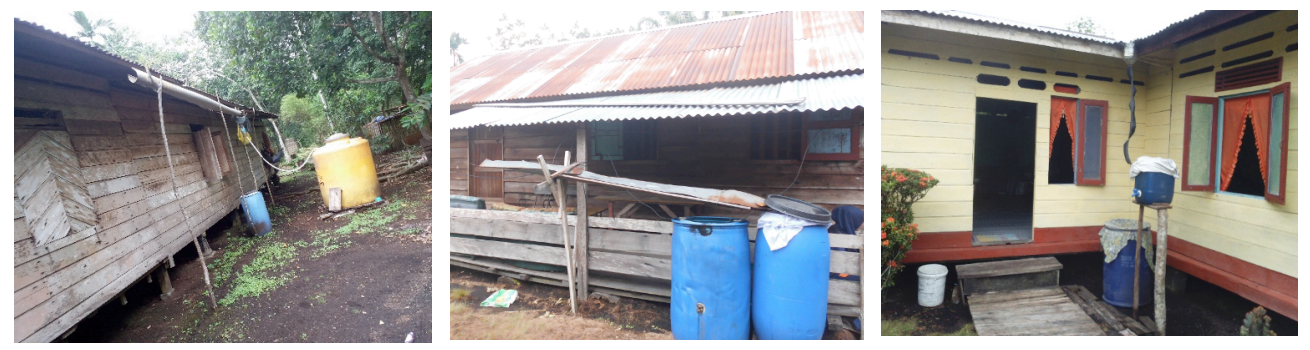

Fig. 4. Traditional rainwater harvesting system in some of the local houses of Merbau Island.

The characteristics of the facilities and the infrastructure of the rainwater harvesting systems in the research site have been presented as follows.

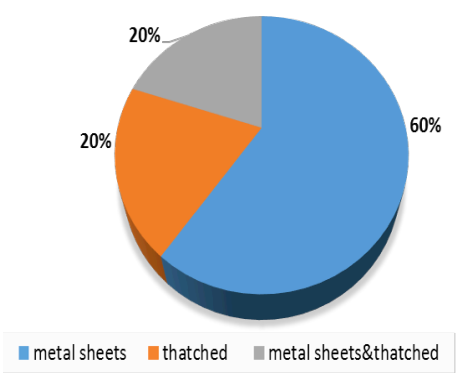

(a)

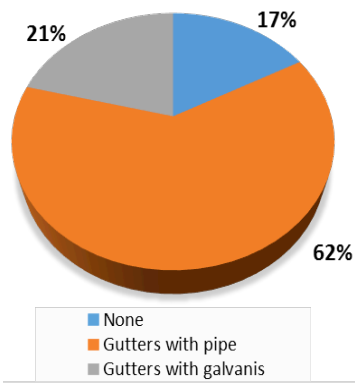

(b)

Fig. 5. Types of rainwater harvesting owned by the locals, (a) types of roof, (b) types of gutter. 
The roofs of the local houses consist of $20 \%$ zinc, $20 \%$ rumbia and $60 \%$ combined tin and rumbia in Fig. 5 (a). Each type of roof will affect the runoff coefficient. The higher the runoff coefficient, the more rain will be collected. The runoff coefficient varies significantly based on the roofing material, roof tilt, and so on [19].

Ramon at al [20] suggested some criteria for selecting roofs to maximize the rainwater availability and quality. Four types of the roof were selected and monitored over a 2-year period, e.g., clay tile roofs, metal sheets, polycarbonate plastics, and flat pebble roofs. Pande \& Telang [21] also suggested that a normal concrete roof has a higher runoff coefficient compared to a thatched roof (rumbia). $90 \%$ of the rainwater will go into the storage if the gutters are correctly installed [22].

The condition of the gutters as the flow tunnel to the storage in each household has been described in Fig. 5 (b) and can be categorized as 'sufficient.' $21 \%$ of gutters are valley roofs with galvanized materials, $17 \%$ are without gutters, and $62 \%$ have simple gutters made from zinc and pipes. With these conditions in mind, rainwater cannot be stored optimally.

Other characteristics described in this study are the types of water container used, and the size of the roof as illustrated in Fig. 6 (a) and 6 (b) 59\% of the containers used are a drum made of fiber. About $6 \%$ of the population does not have any storage for rainwater.

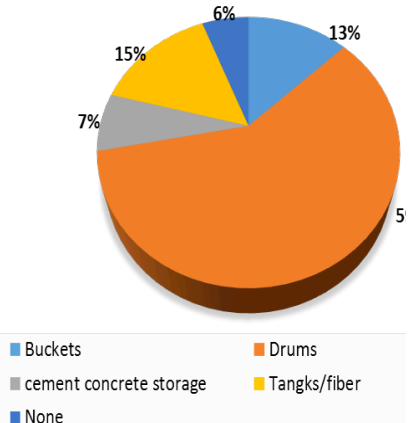

(a)

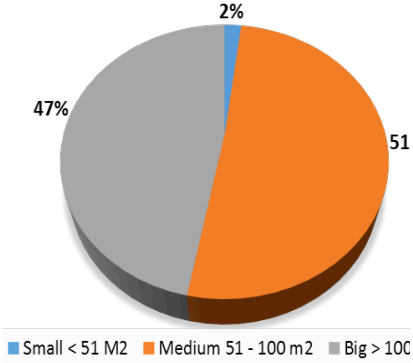

(b)

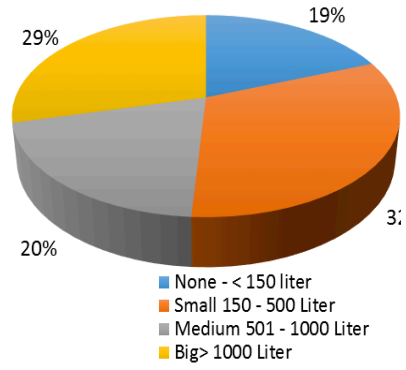

(c)

Fig. 6. The rainwater containers used by the Merbau Island people, (a) types of container, (b) size of roof, (c) water storage tank.

\section{Need analysis of rainwater as a clean water source}

Based on the standard of domestic water needs for a village with less than 20,000 people as the population, it was calculated that the daily water need is about 60 liters per person per day for drinking, cooking, and washing. For a household with 13 people, a house will need a storage capacity of at least $0.780 \mathrm{~m}^{3}$.

Regarding the clean water storage facilities owned by the community as illustrated in Fig. 6.c, it can be concluded that the poverty factor is the dominant influence on people's purchasing power of clean water supply facilities on Merbau Island, where only $29 \%$ of the population have a holding facility that exceeds $1 \mathrm{~m}^{3}$ (1000 liters).

The need for water supply varies from one community to another. The results of Yanuar et al. [23] in Lembang showed that the average water demand for the community was 82.62 liters per day per person. The PDAM can serve, in the city, only 30.72 liters per day per person. Some efforts have been made, such as saving on the use of clean water, and exploring and utilizing the existing resources in the area. The consumption behavior toward clean water is not similar between regions due to the individual characteristics of each region. The consumption pattern of clean water is primarily determined by climate, 
population characteristics, environmental issues, industry and trade, water contributions, city size and water conservation needs [24].

Rachmawati [25] found that there are still many poor individuals who cannot access clean water. Even if they can access the clean water, it is not affordable for them as the price is made higher than normal. The cost that these people spend on clean water could reach up $50 \%$ of their total household expenses. To overcome these problems, local initiatives should be put in place to meet the need for clean water both collectively and individually. From the perspective of these two management systems at the local level, it can be seen how the community's flexibility helps to meet the need for clean water of the population.

Messakh [26] mentioned that the potential water sources, especially in Kupang, are not sufficient enough to meet the drinking water needs. To deal with this, the paradigm of water resource management for multiple sectors needs to be adapted and adjusted to the features of a semi-arid area whose priority is drinking water. The rainfall potential should be optimized for its use as a primary water source by building a dam, other reservoir systems and also by conducting water conservation. Other strategies can also be implemented such as saving water following the local needs and wisdom and regulating the prioritized serving areas for the drinking water pipe system. The use of groundwater as the primary source of raw water must be controlled by considering the supporting capacity of the environment.

\section{Results}

The availability of rainwater on Merbau Island was calculated based on the rain harvesting conducted by each household by considering the size of the roof as the catchment area. Three components should be considered in rainwater harvesting, namely catchment surface, delivery system, and storage reservoir. The three basic components can be seen in Fig. 7.

(1)

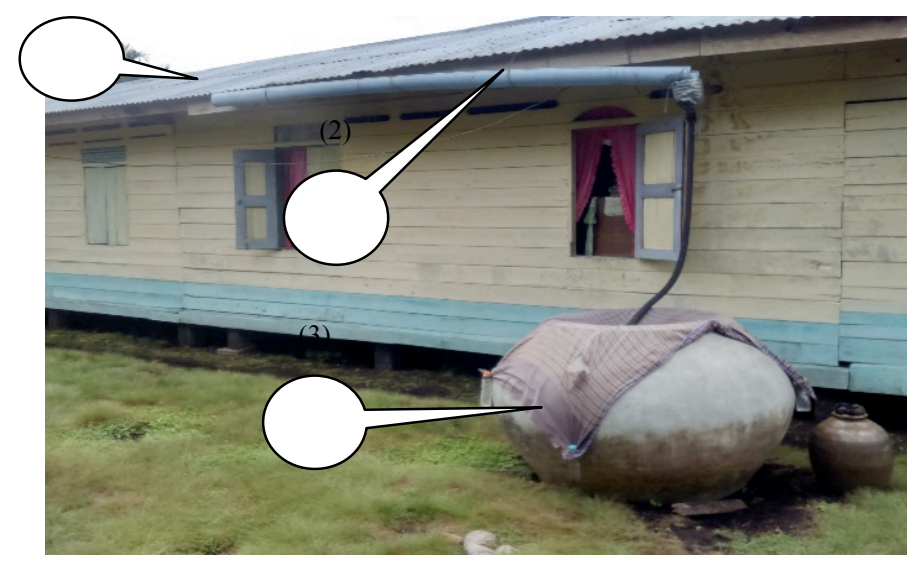

Fig. 7. The main component rainwater harvesting system: catchment area (1), surface delivery (2), system storage reservoir (3).

The calculation of the rainwater potential in the Merbau Islands was conducted with the help of the Rain Cycle v2 software. This simulation generated both a graph and a table of correlation between the volume of the tank and the percentage of rainwater contribution in relation to meeting the domestic water needs over a year. Table 2 and Fig. 8 describes that 
the domestic demands for water can be $100 \%$ fulfilled if the capacity for storage $\left(12 \mathrm{~m}^{3}\right)$ can be provided.

Table 2. Capacity storage of the tank

\begin{tabular}{|c|c|c|c|}
\hline $\begin{array}{c}\text { Tank size } \\
\left(\mathbf{m}^{\mathbf{3}}\right)\end{array}$ & Met (\%) & $\begin{array}{c}\text { Tank size } \\
\left(\mathbf{m}^{\mathbf{3}} \mathbf{)}\right.\end{array}$ & Met (\%) \\
\hline 0 & 0 & 7 & 94.4 \\
\hline 1 & 57.8 & 8 & 97.0 \\
\hline 2 & 74.2 & 9 & 97.8 \\
\hline 3 & 81.5 & 10 & 98.5 \\
\hline 4 & 85.2 & 11 & 99.3 \\
\hline 5 & 88.3 & 12 & 100.0 \\
\hline 6 & 91.3 & 13 & - \\
\hline
\end{tabular}

\section{Tank Size vs. \% of Demand Met Graph}

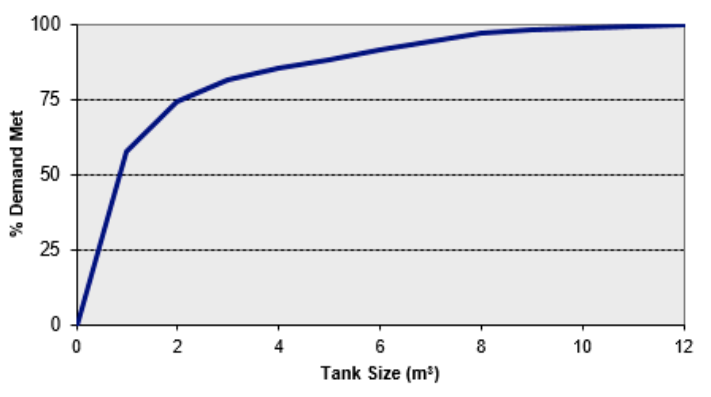

Fig. 8. Tank size versus $\%$ demand met.

The potential for rainwater harvesting was calculated using the average rainfall data over 20 years (1997-2016) by assuming that the average roof size is $213 \mathrm{~m}^{3}$ and that the average roof type is zinc and rumbia, with a coefficient of 0.5 . The results of the rainwater volume for each month can be seen in Table 2 .

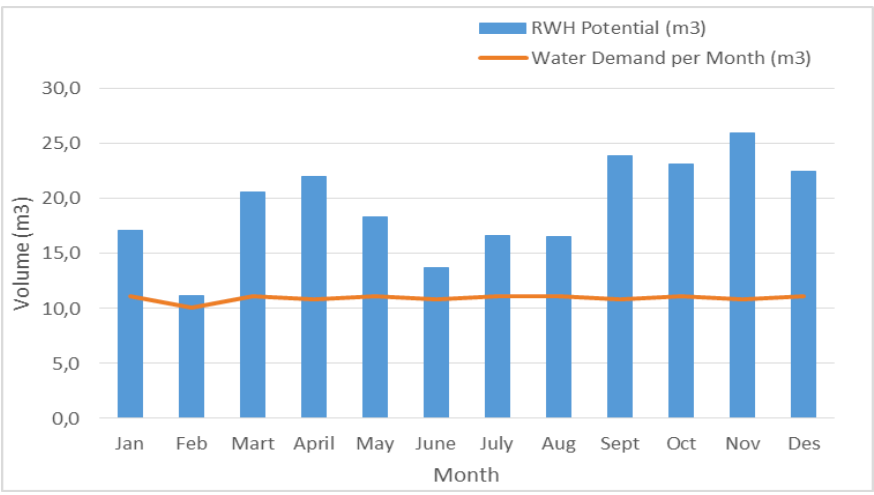

Fig. 9. The availability of rainfall and the monthly need for water. 
Fig. 9 and Fig. 10 display the potential for rainwater availability when RHS is applied.

Derived from Table 3, it can be concluded that the water shortage of Merbau Island can be solved with the proposed roof rainwater harvesting system.

Table 3. Rainwater harvested in the study area between 1997-2016.

\begin{tabular}{|c|c|c|c|c|c|c|c|}
\hline Month & Days & $\begin{array}{c}\text { Mean } \\
\text { monthly- } \\
\text { rainfall } \\
(\mathrm{mm})\end{array}$ & $\begin{array}{c}\text { Monthly } \\
\text { rainfall } \\
\text { harvested } \\
\left(\mathbf{m}^{3}\right)\end{array}$ & $\begin{array}{c}\text { Total } \\
\text { monthly } \\
\text { rainfall } \\
\text { harvested } \\
\left(\mathbf{m}^{3}\right)\end{array}$ & $\begin{array}{c}\text { Demand } \\
\text { base on } \\
\text { total } \\
\text { utilization } \\
\left(\mathbf{m}^{3}\right)\end{array}$ & $\begin{array}{c}\text { Monthly } \\
\text { total } \\
\text { demand } \\
\left(\mathbf{m}^{3}\right)\end{array}$ & $\begin{array}{c}\text { Deviation } \\
(5-7) \\
\left(\mathbf{m}^{3}\right)\end{array}$ \\
\hline 1 & 2 & 3 & 4 & 5 & 6 & 7 & 8 \\
\hline Jan & 31 & 160.5 & 17.1 & 17.1 & 11 & 11.2 & 5.9 \\
\hline Feb & 28 & 105.3 & 11.2 & 28.3 & 10 & 21.2 & 7.1 \\
\hline Mar & 31 & 193.9 & 20.6 & 49.0 & 11 & 32.4 & 16.6 \\
\hline April & 30 & 206.7 & 22.0 & 71.0 & 11 & 43.2 & 27.8 \\
\hline May & 31 & 172.5 & 18.4 & 89.3 & 11 & 54.4 & 35.0 \\
\hline June & 30 & 128.7 & 13.7 & 103.1 & 11 & 65.2 & 37.9 \\
\hline July & 31 & 156.3 & 16.6 & 119.7 & 11 & 76.3 & 43.4 \\
\hline Aug & 31 & 155.8 & 16.6 & 136.3 & 11 & 87.5 & 48.8 \\
\hline Sept & 30 & 224.6 & 23.9 & 160.2 & 11 & 98.3 & 61.9 \\
\hline Oct & 31 & 217.2 & 23.1 & 183.3 & 11 & 109.4 & 73.9 \\
\hline Nov & 30 & 243.6 & 25.9 & 209.3 & 11 & 120.2 & 89.0 \\
\hline Des & 31 & 210.8 & 22.5 & 231.7 & 11 & 131.4 & 100.3 \\
\hline Total & 365 & 179.0 & 231.7 & & 131 & & \\
\hline
\end{tabular}

The total potential of rainwater harvesting is $231.7 \mathrm{~m}^{3}$ per annum, and this is sufficient enough to fulfill the domestic needs of a household such as drinking, cooking and washing. It also implies that this system can be beneficial for other areas with water shortages.

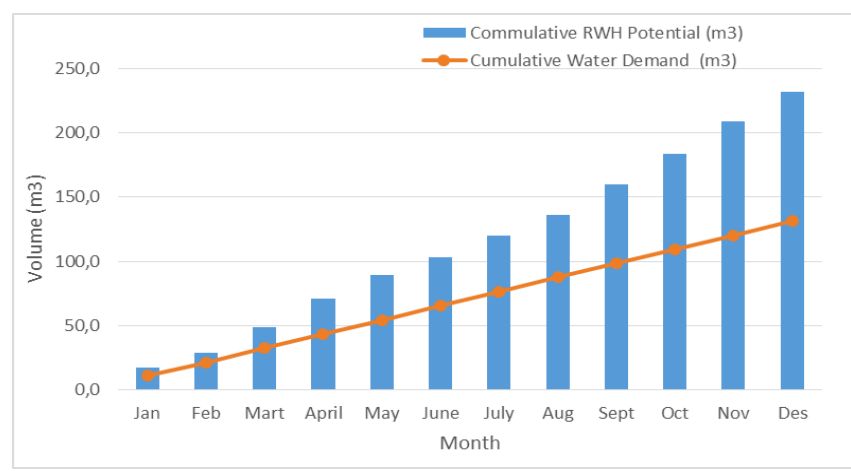


Fig. 10. The cumulative comparison of rainfall availability and the monthly need for water.

However, based on the volume of water collected by the locals as shown in Fig. 8, it can be seen that traditional rainwater harvesting systems cannot meet the need for clean water sustainably. Therefore, there needs to be a community-based reservoir or a bigger rainwater harvesting system to obtain clean water on Merbau Island.

Some previous studies have been discussed, and it was found that the availability of rainwater can help to fulfill the needs of people in areas where water is scarce. These studies also discussed the solutions available when dealing with the issue of limited facilities.

Opera [27] mentioned that the high level of poverty in rural areas indicates that the government needs to provide more financial support in the form of microcredit to some households. This is so then they can afford to install water facilities to fulfill their need for clean water. A budget needs to be allocated to establish a well-based harvesting system to provide a more sustainable system for the local community to allow them to obtain clean water from rainfall.

Chandel dan Sharma [28] developed a permanent framework for household roofs to harvest rainwater domestically by designing rainwater outlets and roofs at their research sites. Sharma mentioned that rain is the primary source of water and that when it is appropriately collected, the issue of water scarcity in most regions can be eliminated.

Tripathi dan Pandey [29] mentioned that rainwater management in local areas is much needed. A decentralized management strategy should be performed by involving the community to encourage them to be able to self-fulfill their need for clean water. Some technical programs for determining the volume of the smallest rainfall harvest tank have been developed for various areas, and they have been used to construct the most costefficient water harvesting tank for specific roof areas. The strategy also needs to build people's awareness by providing both financial and technical support to disseminate the use of rainfall harvesting to respond to the water crisis [30].

\section{Discussion}

By looking into the existing situation of the local Merbau Island communities, it was found that most of the locals live in poverty and cannot afford clean water, only rainwater. However, $14 \%$ of the Merbau people do not have a rainwater reservoir, which means that there is still a significant percentage of the community who cannot access clean water. This situation informs the government, who are focused on policymaking, of the importance of providing the infrastructure and facilities for a rainwater harvesting system.

The government also needs to initiate a program for the Provision of Water Supply and Sanitation Community Based (PAMSIMAS) by involving both the Ministry of Public Works and the Ministry of Health Affairs. Heavy rainfall without a proper reservoir system will only waste the clean water supply available. Communal infrastructures and facilities need to be developed to maximize the collection of rainwater from roofs. Therefore, the participation of the public and the government is required to overcome the economic limitations of the community in relation to meeting the needs of clean water on Merbau Island.

\section{Conclusions}

This study has concluded that rainwater is the sole source of clean water on Merbau Island because surface water and groundwater are acidic with high salinity. When appropriately harvested, the rain collected by each house can be sufficient enough to meet the dweller's 
domestic needs. However, due to the economic situation of Merbau Island's local people, not all can afford to have a proper rainwater harvesting system in their house. Using the available data on average roof area, roof type, the number of household members $213 \mathrm{~m}^{2}$, zinc (0.9) and six people respectively this requires a tank volume of $12 \mathrm{~m}^{2}$ to meet the need for clean water over a year completely.

This article is a part of the Doctoral Dissertation for Environmental Science. The author would like to thank the promoter team for their commitment, constant support, encouragement and tutoring throughout the execution of this research.

\section{References}

1. R. Dauhuri, J. Rais, S.P. Giting, M.J. Sitepu, Pengelolaan sumber daya wilayah pesisir dan lautan secara terpadu (PT Pradnya Paramita, Jakarta, 2001)

2. United Nations Environtment Programme, Global environment outlook 5: environment for the future we want (UNEP, Valleta, 2012)

3. A.I. Che-Ani, N. Shaari, A. Sairi, M.F.M. Zain, M.M. Tahir. European J. of Sci. Res. 34, 1 (2009)

4. S.N. Ngigi. Proc. of the $9^{\text {th }}$ Int. Conf.e in Rainwater Catchment Cistern Sys. (1999)

5. T. Thomas, Building Res. \& Information 26, 2 (2010)

6. K.J. An, Y. F. Lam, S. Hao, T.E. Morakinyo, H. Furumai, Water Res. 30 (2015)

7. E.L. Villarreal, A. Dixon, Building and Env. 40, 9 (2005)

8. D. Adugna, M.B. Jensen, B. Lemma, G.S. Gebrie, Int. J. of Env. Res. and Public Health 15, 2 (2018)

9. S. Jain, P. Thakur, S. Singh, M. Srivastava, SSRG-Int. J. of Civil Eng. 2, 7 (2015)

10. J.R. Julius, R.A. Prabhavathy, G. Ravikumar, Int. J. of Sci. and Engi. Res. 4, 8 (2013)

11. R.O. Ojwang, J. Dietrich, P.K. Anebagilu, M. Beyer, F. Rottensteiner, Water 9 (2017)

12. S. Bhattacharya. Int. Letters of Natural Sci. 37 (2015)

13. Pemerintah Daerah Kepulauan Meranti. Profil Pulau Merbau. Kecamatan Pulau Merbau (Pemerintah Daerah Kepulauan Meranti, 2015)

14. Direktorat Pulau-pulau Kecil Indonesia. Merbau. Available at http://www.ppkkp3k.kkp.go.id/direktori-pulau/index.php/public_c/pulau_info/ 382\#gu (2012)

15. Pemerintah Daerah Kabupaten Kepulauan Meranti. Program percepatan pembangunan sanitasi permukiman, Buku putih sanitasi Kabupaten Kepulauan Meranti (Badan Perencanaan Pembangunan Daerah Kabupaten Kepulauan Meranti, 2014)

16. Tukidi, Jurnal Geografi 7, 2 (2010)

17. J. Worm, T.V. Hattum, Rainwater harvesting for domestic use (Agromisa Foundation and CTA, Wageningen, 2006)

18. Badan Pusat Statistik, Kabupaten Kepulauan Meranti. Available at https://merantikab.bps.go.id (2012-2016)

19. B.K. Biswas, B.H. Mandal, International Scholarly Research Notices (2014)

20. F. Ramon, M.P. Tito, G. Albert, T. Carlota, R. Joan, G. Xavier. Water Res. 45, 10 (2011)

21. P. Pande, S. Telang. Global Adv. Res. J. of Agr. 3, 7 (2014)

22. V.I. Otti, E.E. Ezenwaji, Int. J. of Eng. and Tech. 3, 1 (2013) 
23. M. Yanuar, D. Rohmat, Jupri, Antologi Geografi 4, 1 (2016)

24. I.B.Suryadmaja, I.N. Norken, I.G.B.S. Dharma. Jurnal Spektran 3, 1 (2015)

25. L. Rachmawati, G.A.K. Surtian, Jurnal Kependudukan Indonesia 6, 2 (2016)

26. J.J. Messakh, A. Sabar, I.K. Hadihardaja, A.A. Chalik. Jurnal Manusia \& Lingkungan 22, 3 (2015)

27. S. Opare, GeoJournal 77, 5 (2012)

28. R.S. Chandel, M.R. Sharma, Asian Journal of Adv. Basic Science 3, 1 (2014)

29. A.K. Tripathi, U.K. Pandey, Journal of Human Ecology 18, 1 (2005)

30. A.Z. Majed, H. Ayat, M. Shatanawi, Urban. Water J. 1, 1-7 (2012) 